\title{
Response
}

\section{Response to reviews of Governing Social Risks in Post-Crisis Europe}

Colin Crouch, Max Planck Institute for the Study of Societies, Germany; University of Warwick, UK

Matt Vidal is right to see a connection between this book and my earlier Capitalist Diversity and Change. Governing Social Risks is indeed an attempt to practise the methodologies I commended in the earlier book. This had been a critique of the comparative capitalism literature for its insistence on forming typologies based on a few characteristics, and then forcing all empirical cases into its small number of types (usually two or three). Too much violence is done to the complexities of individual cases, I argued, and not enough account is taken of contradictory elements within the institutional mixes of cases, contradictions that might be vital to their sustainability. These problems are particularly severe when the units of comparison are countries, as they must be for comparative capitalist studies, where the number of variables always exceeds the number of cases.

In Capitalist Diversity and Change I also complained about what I called 'methodological nationalism', the assumption by comparative researchers that nation states constitute wholes, ignoring institutional fault lines within them. At present this is seen most strongly in the way that we all now use data about Germany without much reference to the fact that such an entity in its present form has existed only since 1990. In Governing Social Risks I have not learned this lesson at all, but have, if only for reasons of data availability, been a thorough-going methodological nationalist. My reviewers have in turn done the same.

The problems that all three reviewers see with Governing Social Risks explain why so many authors adopt the simple typology approach. Although at the end of the book I try to extract some general conclusions, as Janine Leschke in particular appreciates, in general I am demonstrating complexity. By both using a large number of indicators and refusing to suppress non-conforming evidence in order to make clear types, I leave the reader without a clear story line. Further, although the book is policy-oriented, I have no 
clear message for policy makers. As Vidal points out, the Nordic countries appear as having the most favourable institutional mixes (and I can hardly claim that as an original finding!), but I do not demonstrate how or even whether some other countries might imitate them. I do, however, point out that the tendency of much national and European policy to destroy the leading characteristics of the Nordic cases is ill advised. No government official or political think tank expert is going to wave my book around and say that it contains a clear alternative. Does that mean that in future I shall mend my ways and try simpler forms of analysis? No. Someone has to point out that things are less coherent, messier, more affected by the details of individual contexts than they are usually presented as being. One ends up being something of a spoilsport, providing just a corrective to others' bolder narratives, but there is a place for correctives. It is usually a role played by historians rather than social scientists, but it is important to take historians' lessons on board. If anything, if one had space and life enough to carry out a larger project, and the possible existence of a few readers with adequate patience to absorb the result, I would want to go further in the same direction and provide richer contextual and historical material. I am guilty of over simplification myself. Trying in one book to deal with the whole of Europe with some external comparators too requires a reduction to quantitative indicators, which at times, as the reviewers all point out, can lead one to draw false conclusions about similarities.

Two important points made in Richard Hyman's review merit attention, concerning trade union power and community governance. As he says, I use a combined measure of trade union membership and measures of union and worker representation in government and corporate institutions to measure what I call 'class challenge', since from my perspective only trade unions can mount challenges to the exercise of employer power within both economy and polity. Whether to regard incorporation as evidence of working-class power or as its castration is a long-standing disagreement among observers of employment relations, and it depends ultimately on their different perspective on political possibilities. Richard and I have always been on different sides of that dispute and we shall probably never resolve it. However, here he raises a specific and powerful objection that both membership and institutional incorporation can atrophy and cease to signify what they did at an earlier moment. I do not consider that this has happened yet within Europe; otherwise one would not see such different policies and practices between countries with strong and weak unions. But we are probably standing at a cusp where this is about to happen. In particular in countries like Germany, Austria and the Netherlands, where the level of incorporation is higher than current union memberships could achieve if they had to fight for it, the viability of these structures must be in doubt. We have already seen how the collapse of union memberships in central Europe has led to the complete marginalization of worker representation. Those institutions for representing employee interests that do exist in most central European countries are there only as a result of the acquis communautaire of European Union membership and often not implemented.

In his dissatisfaction with measures of union activities as an indicator of workers' strength, Hyman logically questions my reduction of community governance of employment relations to a mix of the shadow economy, the inability of sons to leave home and the volume of remissions from family members working abroad. These were the only 
indicators I could find that came anything near what I understood by the informal defensive arrangements that workers often use to provide security when other institutions have failed them. I should be very happy to find evidence of more constructive examples of the type Hyman mentions; they certainly exist, but there are no good comparative measures of them. But even my limited indicators support Hyman's main point. I found these mechanisms to exist in inverse proportion to the availability of market or social policy forms of support against insecurity, mainly in southern and central Europe. They are evidence of how people are trying to cope, sometimes creatively, though I would still insist that they are desperate remedies, evidence of a failing capacity of better established institutions to protect workers in Europe and elsewhere from the turbulence of the global economy. 